\title{
Precision of helicopter-based total-area counts of large ungulates in bushveld
}

\author{
B.K. REILLY
}

Reilly, B.K. 2002. Precision of helicopter-based total-area counts of large ungulates in bushveld. Koedoe 45(2): 77-83. Pretoria. ISSN 0075-6458.

Precision in helicopter total-area counts in bushveld for a range of common species are evaluated. Counts were conducted on properties ranging in size from 250 ha to 10000 ha as part of experiments on precision and power. Counts were conducted in three vegetation types: mopane veld, sourish mixed bushveld and arid bushveld. Scant regard is given to precision as a factor in large herbivore monitoring, with more effort often devoted to accuracy. Coefficients of variation varied from $3.2 \%$ to $70.9 \%$. Median values are generally acceptable for the establishment of trends for long-term monitoring, but might be inadequate for annual population size monitoring and evaluation. A regression of all species and vegetation types by the standard error showed a significant correlation. Similar regressions were also developed for impala, kudu, warthog, and zebra. Regressions by vegetation type for mopane veld, sourish mixed bushveld, and northwest arid bushveld were also significant. However, the high correlation for some vegetation types might be an artifact of the small sample sizes.

Keywords: census, game counting, helicopter counts, impala, kudu, zebra, wildebeest, giraffe, large herbivore monitoring.

B.K. Reilly, Department of Nature Conservation, Technikon Pretoria, Private Bag X680, Pretoria, 0001, Republic of South Africa.

\section{Introduction}

Precision of game counts is often neglected in the development of aerial large ungulate counting strategies. Replicated counts provide opportunities to assess the precision of the total-area helicopter counts for a range of species and conservation areas.

The use of aerial surveys as a tool in the monitoring of large ungulates can be traced back to 1935 (Cahalane 1938). The use of aircraft, particularly helicopters, has grown consistently since the 1950s and today is almost universally applied in enumerating many ungulate species, for example, white tailed deer, Oidocoileus virginianus (Beasom et al. 1986), mule deer, Oidocoileus hemionus (Bartman et al. 1986) and elk, Cervus elaphus in Michigan (Otten et al. 1993). Furthermore, total counts have been applied to many species of African ungulates and results have been recorded by several authors. Van Lavieren \& Esser (1979) report results of counts of giant eland Tragelaphus derbianus, roan antelope Hippotragus equinus, defassa waterbuck Kobus ellipsiprymnus defassa, bohor reedbuck Redunca redunca and Bubal hartebeest Alcelaphus buselaphus in west Africa and several species such as impala Aepyceros melampus, topi Damaliscus lunatus, sitatunga Tragelaphus spekii, eland Tragelaphus oryx and waterbuck Kobus ellipsiprymnus in Rwanda. Total counts have been used in East Africa (Dasmann \& Mossman 1962; Jolly 1969) and in South Africa (Hirst 1969; Goodman 1977; Melton 1978; Collinson 1985; Bothma et al. 1990; Eiselen 1994; Van Hensbergen et al. 1996).

Total aerial counts have moved beyond application in protected areas and, particularly in the South African context, are now widely applied to monitor population size on commercial game ranches. For smaller prop- 
erties it provides information in a short time and is less sensitive to habitat diversity and ungulate population sizes than many other sampling methods. In most bushveld applications visibility from the air is also generally better than from the ground.

The helicopter surveys have, however, many detractors due often to failure to ensure that underlying assumptions have been met (Caughley 1974; Melton 1978). The requirement for experienced observers, poor performance caused by observer fatigue, difficulty in standardisation of methodology between (and within) counts, and high costs often mitigate against the technique (Caughley 1979; Norton-Griffiths 1978; Seber 1992). Consequently, these methods are often applied by inexperienced staff who are unschooled in the underlying principles involved. The non-standardisation of approaches to game counts, in general, lengthens the causal chain of poor precision. Yet, it remains the census technique of choice in South Africa. This could be due to a misconception that number of animals counted equate to the actual population size, i.e., the technique is accurate.

The accuracy of helicopter counts has been questioned (Rice \& Harder 1977; Beasom 1979; Payne 1981; De Young 1985; Beasom et al. 1986; Seber 1992; Bothma et al.1990) and the effect of various factors, for example, height and speed, on accuracy is unclear. Other investigations quantify observer bias (Pennycuick \& Western 1972; Norton-Griffiths 1978; Melton 1978; Graham \& Bell 1989) but there are few references on precision and power of these applications. Each survey produces a count of the population, which is some fraction, hopefully large, of the actual population. In practice, individual counts differ for a variety of reasons, including systematic and random errors. The extent to which repeated counts differ can be stated in terms of the precision of a count. If precision is high, then repeated counts would all have similar values. When repeated survey counts of a population are conducted, the results will vary because of a variety of factors.
Beasom (1979) reports variations in replicated helicopter counts in Texas, ranging from $0.9 \%$ to $32.3 \%$, while Le Resche \& Rausch (1974) report coefficients of variation ranging from $16 \%$ to $41 \%$ in fixed-wing counts of moose. They also report significantly lower CVs in some seasons (spring, $p<$ 0.05). Hirst (1969) recorded variability of $12.8 \%$ to $32.2 \%$ on strip counts of blesbok on Rietvlei Nature Reserve. Beasom (1979) indicates a significant negative correlation between $\mathrm{CV}$ and mean estimated deer population and area size. Rice \& Harder (1977) comment on the high precision attained using helicopters for mark-recapture counts in Ohio and reports a CV of $7 \%$. McCullough (1994), in documenting herd composition counts of black tailed deer, describes large variances, and consequently questioning the value of the data in decision making.

This study analyses replicate count data from several typical bushveld total helicopter surveys in an effort to quantify precision in addition to power analyses results published by Reilly(2000) and Brockett (in press).

\section{Study areas}

Three study areas comprised 1) an 8500-ha block located in the Loskop Dam Nature Reserve situated in sourish mixed bushveld (Acocks veldtype 19), (Acocks 1988); 2) a number of conservation areas surrounding Atherstone Nature Reserve (ranging in size from 500 ha to 2500 ha) situated in arid bushveld (Acocks veldtype 18); and 3) two areas in mopane veld (Acocks veldtype 15) - a 10000-ha block of Letaba Ranch in the Limpopo Province, and five conservation areas adjacent to the Dongola Nature Reserve (ranging in size from 250 ha to 1500 ha) in Limpopo Province, also in mopane veld. All areas fall in the savanna biome.

\section{Method}

\section{Data collection}

The method has been described in detail by Reilly (2000). A summary of the methodology was as follows: strips ( $330 \mathrm{~m}$ wide) were flown by heading and counter heading, tracked by a navigator using aerial 
photos, 1:50 000 topocadastral maps and a grid overlay of $1 \mathrm{~km}^{2}$. Flying at $96 \mathrm{~km} / \mathrm{h}$, an attempt was made to cover the total area. Height was regulated using a radar altimeter set at $53 \mathrm{~m}$ above ground level and counts were accomplished with the rear doors removed. All counts were done between July and September, post leaf drop. Replicates were conducted on consecutive days but at the same time of day, and using the same observers. Handheld tape recorders were used to record data and were later transcribed to data sheets using the grid numbers of the overlay. All ungulate species seen were counted and, where necessary, herds were flushed to ensure accurate enumeration. During each aerial survey on a property an attempt is made to completely enumerate the population of each species.

\section{Data analysis}

Precision is most commonly stated in terms of a variance or standard deviation, or may be scaled and presented in the form of a coefficient of variation. In this study, coefficients of variation are used to present information on relative precision since the absolute sizes of populations differ greatly, both between species and between sites.

The coefficient of variation (CV) is a scaled measure of precision that provides a useful indication of a technique's ability to show change over time. Precision of the counts is expressed as a coefficient of variation (scaled measure of dispersion that allows for comparison between sites), i.e., where $s$ is the sample standard deviation and $\bar{x}$ (x bar) the mean of the replicate counts.

$C V=\frac{s}{\bar{x}}(100)$

The median value of each set of CVs for each species provides a measure of location of the sample that is insensitive to outliers.

\section{Bootstrapped standard deviation}

Each survey can be considered as an independent sample from the population of all possible surveys for that site. To estimate the variance of these counts, the standard estimator of variance could be used but this is problematic since we need to know the estimate of variance for the statistical population of enumerable counts rather than sample parameters obtained from the three and four replicates. To over- come this problem the estimate of the variance was obtained by bootstrapping (Efron 1974).

Samples (4000) were generated randomly with replacement from the sample values. From each of these samples, a variance was calculated. The mean of these variances is an estimate of the statistical population variance. Other measures of dispersion (standard error) were then based on these estimators.

\section{Correlations for species and vegetation type}

A regression analysis for all species and vegetation type (site) of the mean count (population) size by the standard error (SE) was also conducted. For the purpose of discussion in the following review of results by species and area-habitat type the $\mathrm{CV}$ was used as a measure of precision.

\section{Results}

Estimates of precision derived from bootstrap replications are presented in Table 1 as means, standard errors of the mean and as coefficients of variation. It can be seen that there is considerable variation in the estimates of $\mathrm{CV}$, they range from $<5.3 \%$ to $>70 \%$ for some species.

\section{$K u d u$}

Ten estimates of precision were obtained for kudu ranging from $5.3 \%$ to $54.2 \%$ with a median of $14.6 \%(n=10)$. Single observations were obtained for lowveld mopane veld and the sourish mixed bushveld $(29.6 \%$ and $5.3 \%$ respectively). The results for the northern mopane veld were poor with a high of $70.9 \%$, while a median for five observations in northwestern arid bushveld had a precision of $12.5 \%$.

\section{Zebra}

Six estimates of precision were obtained for zebra with CVs ranging from $4.9 \%$ to $61.9 \%$. Single observations for lowveld mopane veld, sourish mixed bushveld and northwestern arid bushveld were $18.6 \%$, $7.2 \%$ and $11.3 \%$, respectively. The median of three observations for northern mopane veld is $9.8 \%$. 
Table 1

Summary precision data for 61 observations during this study

\begin{tabular}{|c|c|c|c|c|c|c|c|c|c|}
\hline \multirow[t]{2}{*}{ Study site } & \multirow[t]{2}{*}{ Species } & \multicolumn{4}{|c|}{ Count Replicates } & \multirow[t]{2}{*}{ Mean } & \multirow{2}{*}{$\begin{array}{l}\text { Bootstrapped } \\
\text { SD }\end{array}$} & \multirow[t]{2}{*}{$\mathrm{SE}$} & \multirow[t]{2}{*}{$\mathrm{CV}$} \\
\hline & & 1 & 2 & 3 & 4 & & & & \\
\hline Letaba Ranch & Kudu & 25 & 48 & 57 & 35 & 41.3 & 12.2 & 6.1 & 29.6 \\
\hline \multirow[t]{4}{*}{ Mopanieveld } & Zebra & 76 & 60 & 54 & 46 & 59.0 & 11.0 & 5.5 & 18.6 \\
\hline & Wildebeest & 67 & 62 & 59 & 70 & 64.5 & 4.4 & 2.2 & 6.8 \\
\hline & Impala & 633 & 727 & 615 & 446 & 605.3 & 102.4 & 51.2 & 16.9 \\
\hline & Giraffe & 25 & 48 & 57 & 35 & 41.3 & 12.4 & 6.2 & 30.1 \\
\hline Loskop Dam & Kudu & 263 & 274 & 260 & 237 & 258.5 & 13.8 & 6.9 & 5.3 \\
\hline \multirow[t]{8}{*}{ Mixed Bushveld } & Zebra & 262 & 236 & 243 & 214 & 238.8 & 17.2 & 8.6 & 7.2 \\
\hline & Wildebeest & 160 & 192 & 200 & 192 & 186.0 & 15.2 & 7.6 & 8.2 \\
\hline & Impala & 285 & 346 & 291 & 345 & 316.8 & 28.6 & 14.3 & 9.0 \\
\hline & Giraffe & 33 & 14 & 19 & 26 & 23.0 & 7.2 & 3.6 & 31.3 \\
\hline & Warthog & 35 & 37 & 46 & 37 & 38.8 & 4.2 & 2.1 & 10.8 \\
\hline & Sable & 43 & 41 & 45 & 36 & 41.3 & 3.4 & 1.7 & 8.2 \\
\hline & White rhino & 32 & 33 & 25 & 30 & 30.0 & 3.2 & 1.6 & 10.7 \\
\hline & $\begin{array}{l}\text { Mountain } \\
\text { reedbuck }\end{array}$ & 163 & 149 & 170 & 141 & 155.8 & 11.4 & 5.7 & 7.3 \\
\hline Vhembe & Kudu & 3 & 13 & 7 & & 7.7 & 4.2 & 2.4 & 54.2 \\
\hline \multirow[t]{25}{*}{ Mopanieveld } & Kudu & 26 & 30 & 50 & & 35.3 & 10.4 & 6.0 & 29.4 \\
\hline & Kudu & 28 & 26 & 21 & & 25.0 & 2.9 & 1.7 & 11.8 \\
\hline & Zebra & 13 & 3 & 5 & & 7.0 & 4.3 & 2.5 & 61.9 \\
\hline & Zebra & 55 & 55 & 61 & & 57.0 & 2.8 & 1.6 & 4.9 \\
\hline & Zebra & 24 & 25 & 20 & & 23.0 & 2.3 & 1.3 & 9.8 \\
\hline & Wildebeest & 23 & 0 & 21 & & 14.7 & 10.4 & 6.0 & 70.9 \\
\hline & Wildebeest & 94 & 106 & 100 & & 100.0 & 4.8 & 2.8 & 4.8 \\
\hline & Wildebeest & 32 & 76 & 54 & & 54.0 & 18.0 & 10.4 & 33.4 \\
\hline & Wildebeest & 70 & 64 & 69 & & 67.7 & 2.6 & 1.5 & 3.8 \\
\hline & Impala & 120 & 85 & 122 & & 109.0 & 17.1 & 9.9 & 15.7 \\
\hline & Impala & 210 & 160 & 178 & & 182.7 & 20.4 & 11.8 & 11.2 \\
\hline & Impala & 122 & 114 & 137 & & 124.3 & 9.5 & 5.5 & 7.7 \\
\hline & Impala & 175 & 288 & 372 & & 278.3 & 81.9 & 47.3 & 29.4 \\
\hline & Giraffe & 22 & 18 & 21 & & 20.3 & 1.7 & 1.0 & 8.5 \\
\hline & Giraffe & 4 & 4 & 4 & & 4.0 & 0.0 & 0.0 & 0.0 \\
\hline & Warthog & 5 & 3 & 2 & & 3.3 & 1.2 & 0.7 & 36.4 \\
\hline & Warthog & 21 & 26 & 11 & & 19.3 & 6.2 & 3.6 & 32.3 \\
\hline & Eland & 3 & 7 & 3 & & 4.3 & 1.9 & 1.1 & 44.0 \\
\hline & Eland & 5 & 11 & 10 & & 8.7 & 2.6 & 1.5 & 30.0 \\
\hline & Eland & 5 & 3 & 2 & & 3.3 & 1.2 & 0.7 & 36.4 \\
\hline & Hartebeest & 22 & 15 & 26 & & 21.0 & 6.2 & 3.6 & 29.7 \\
\hline & Gemsbok & 26 & 27 & 28 & & 27.0 & 0.9 & 0.5 & 3.2 \\
\hline & Waterbuck & 5 & 14 & 16 & & 11.7 & 4.8 & 2.8 & 41.6 \\
\hline & Waterbuck & 27 & 15 & 15 & & 19.0 & 5.7 & 3.3 & 30.1 \\
\hline & Waterbuck & 12 & 10 & 12 & & 11.3 & 0.9 & 0.5 & 7.6 \\
\hline Athersone & Kudu & 132 & 116 & 108 & & 118.7 & 9.9 & 5.7 & 8.3 \\
\hline NW Arid & Kudu & 22 & 26 & 33 & & 27.0 & 4.5 & 2.6 & 16.7 \\
\hline \multirow[t]{5}{*}{ Bushveld } & Kudu & 19 & 33 & 24 & & 25.3 & 5.7 & 3.3 & 22.6 \\
\hline & Kudu & 34 & 33 & 28 & & 31.7 & 2.6 & 1.5 & 8.2 \\
\hline & Kudu & 9 & 7 & 9 & & 8.3 & 1.0 & 0.6 & 12.5 \\
\hline & Zebra & 37 & 39 & 30 & & 35.3 & 4.0 & 2.3 & 11.3 \\
\hline & Wildebeest & 219 & 185 & 230 & & 211.3 & 19.1 & 11.0 & 9.0 \\
\hline
\end{tabular}


Table 1

(continued)

\begin{tabular}{|c|c|c|c|c|c|c|c|c|c|}
\hline \multirow[t]{2}{*}{ Study site } & \multirow[t]{2}{*}{ Species } & \multicolumn{4}{|c|}{ Count Replicates } & \multirow[t]{2}{*}{ Mean } & \multirow{2}{*}{$\begin{array}{c}\text { Bootstrapped } \\
\text { SD }\end{array}$} & \multirow[t]{2}{*}{ SE } & \multirow[t]{2}{*}{$\mathrm{CV}$} \\
\hline & & 1 & 2 & 3 & 4 & & & & \\
\hline & Impala & 477 & 477 & 346 & & 433.3 & 62.0 & 35.8 & 14.3 \\
\hline & Impala & 117 & 78 & 123 & & 106.0 & 19.7 & 11.4 & 18.6 \\
\hline & Impala & 17 & 16 & 0 & & 11.0 & 7.8 & 4.5 & 70.9 \\
\hline & Impala & 141 & 179 & 167 & & 162.3 & 15.8 & 9.1 & 9.7 \\
\hline & Impala & 69 & 82 & 66 & & 72.3 & 6.9 & 4.0 & 9.6 \\
\hline & Warthog & 87 & 79 & 32 & & 66.0 & 24.9 & 14.4 & 37.8 \\
\hline & Warthog & 71 & 81 & 49 & & 67.0 & 13.5 & 7.8 & 20.2 \\
\hline & Warthog & 52 & 29 & 36 & & 39.0 & 9.7 & 5.6 & 24.9 \\
\hline & Warthog & 54 & 33 & 41 & & 42.7 & 8.7 & 5.0 & 20.3 \\
\hline & Warthog & 67 & 39 & 27 & & 44.3 & 16.3 & 9.4 & 36.7 \\
\hline & Hartebeest & 7 & 10 & 32 & & 16.3 & 11.1 & 6.4 & 67.9 \\
\hline & Hartebeest & 29 & 22 & 30 & & 27.0 & 3.6 & 2.1 & 13.5 \\
\hline & Hartebeest & 79 & 91 & 71 & & 80.3 & 8.3 & 4.8 & 10.3 \\
\hline & Waterbuck & 18 & 23 & 29 & & 23.3 & 4.5 & 2.6 & 19.3 \\
\hline
\end{tabular}

\section{Blue wildebeest}

Similarly, in the case of blue wildebeest, seven $\mathrm{CVs}$ obtained range from $3.8 \%$ to $70.9 \%$ with a median of $8.2 \%$. The CVs for lowveld mopane veld, sourish mixed bushveld and arid bushveld are $6.8 \%, 8.2 \%$ and $9.0 \%$ respectively while a median of $19.1 \%$ was obtained for the northern mopane veld.

\section{Impala}

Eleven estimates of precision were obtained for impala with CVs ranging from the high of $70.9 \%$ to $7.7 \%$ with a median of $14.3 \%$. Single values for lowveld mopane veld and sourish mixed bushveld are $16.9 \%$ and $9.0 \%$, respectively. The median $\mathrm{CV}$ for northern mopane veld is $9.5 \%$ and that for northwestern arid bushveld $9.7 \%$.

\section{Giraffe}

There were only four estimates of precision obtained for giraffe with CVs of $30.1 \%$; $31.3 \% ; 19.0 \%$ and $0 \%$ for lowveld mopane veld, sourish mixed bushveld and the last two for northern mopane veld, respectively. This computes to a median of $24.6 \%$.

All results for other species are presented in Table 1.

The regression analysis for all species and vegetation type (site) of the mean count (population) size by the standard error (SE) shows significant correlation $\left(r^{2}=0.71\right.$; $p<0.074 ; n=63)$. This is an indication that the $\mathrm{CV}$ is constant in relation to population size indicating that the technique is robust. Similar regressions by species for those species having several observations show a similar result. For impala, $r^{2}=0.67$, $p<0.002, n=10$; kudu, $r^{2}=0.39, p<0.054$, $n=9$; warthog, $r^{2}=0.64, p<0.018, n=7$; and zebra, $r^{2}=0.86, p<0.021, n=8$. In the case of wildebeest however, the result is not significant $\left(r^{2}=0.17, p<0.361, n=6\right)$.

Further regression analysis by vegetation type shows significant coefficients of determination for lowveld mopane veld (Letaba Ranch) $\left(r^{2}=0.99, p<0.001, n=4\right)$; sourish mixed bushveld (Loskop Dam) $\left(r^{2}=0.86\right.$, $p<0.001, n=8)$; Northern mopane veld (Vhembe) $\left(r^{2}=0.72, p<0.01, n=25\right)$ and arid bushveld (Atherstone) $\left(r^{2}=0.81\right.$, 
$p<0.01, n=20)$. The first mentioned of these could be an artefact of small sample size however.

\section{Discussion}

Comparing these results with other published results (Hirst 1969; Le Resche \& Rausch 1974; Rice \& Harder 1977; Beasom 1979; McCullough 1994; Brockett 2002) suggest that generally these results obtained appear consistent in range with those of other authors and are mainly unpredictable.

The role of precision in monitoring is often misunderstood; in essence the precision can be seen as the "best minimum estimate" of ability of a chosen technique or application to show change in a population over time. This relates back to the fact that monitoring techniques show two sources of variation, real change over time and "within technique variation" which is an artifact of all contributory biases from the physical application of the technique. Misconstruing the last mentioned as real change is statistically termed a Type I error. The CV can be seen as a valuable guide in that a $\mathrm{CV}$ value less than the population change (\%) to be detected increases the probability of showing real change over time whilst a CV that exceeds percentage change to be detected increases the probability of the change shown having actually not taken place in reality. Singlepass aerial surveys or any other monitoring results that are unreplicated or lacking in a strategy to estimate precision cannot fulfill the role of decision support in this regard.

In this study the means of the $\mathrm{CV}$ indicate that, in most cases, the precision is inadequate for decision making on an annual basis, making the use of single-pass surveys doubtful as a decision support tool in ungulate management. The ranges of results also indicate precision to be highly variable. To improve the situation, extending the time between counts will increase the change to be detected, thence improving the probability of detecting real change rather than artifacts related to external sources of bias.

\section{References}

ACOCKS, J.P.H. 1988. Veld types of South Africa. Memoirs of the Botanical Survey of South Africa 57:1-146.

Bartmann, R.M.; L.H. Carpenter; R.A. Garrott \& D.C. BowDEN. 1986. Accuracy of helicopter counts of mule deer in pinyon-juniper woodland. Wildlife Society Bulletin 14(4): 356-363.

Beasom, S. L. 1979. Precision in helicopter censusing of white-tailed deer. Journal of Wildlife Management 43(3): 777-780.

Beasom, S.L.; F.G. LeON III \& D.R. Synatzske. 1986. Accuracy and precision of counting whitetailed deer with helicopters at different sampling intensities. Wildlife Society Bulletin 14(4): 364-368.

Bothma, J. Du P.; M.J.S. Peel; S. Pettit \& D. Grossman. 1990. Evaluating the accuracy of some commonly used game-counting methods. South African Journal of Wildlife Research 20(1): 26-32.

BROCKETT, B.H. 2002. Accuracy, precision and bias of helicopter-based counts of black rhinoceros in Pilanesburg National Park, South Africa. South African Journal of Wildlife Research 32(2): 121136.

Cahalane, V.H. 1938. The annual northern Yellowstone elk herd count. Transactions of the North American Wildlife Conference 3: 388-389.

Caughley, G. 1974. Bias in aerial survey. Journal of Wildlife Management 38: 921-933.

Caughley, G. 1979. Analysis of vertebrate populations. New York: Wiley.

Collinson, R.H.F. 1985. Selecting Wildlife Census Techniques. Monograph 6, Institute of Natural Resources, University of Natal, Pietermaritzburg.

Dasmann, R.F. \& A.S. Mossman. 1962. Road strip counts for estimating numbers of African ungulates. Journal of Wildlife Management 26: 101-104.

DeYoung, C. A. 1985. Accuracy of helicopter surveys of deer in south Texas. Wildlife Society Bulletin 13 (2): 146-149.

EFron, B. 1979. Bootstrap methods: another look at the jackknife. Annals of Statistics 7(1): 1-26.

EISELEN, R. 1994. Estimating the trends in herbivore numbers in the southern district of the Kruger National Park. South African Journal of Wildlife Research 24(4): 95-100.

GerRodette, T. 1993. Trends: Software for a power analysis of linear regression. Wildlife Society Bulletin 21: 515-516.

GoODMAN, P.S. 1977. An evaluation of three techniques for estimating animal numbers in a wildlife population. Unpub. Mimeographed Report., Natal Parks Board, Pietermaritzburg.

GRAHAM, A. \& R. Bell. 1989. Investigating observer bias in aerial survey by simultaneous double- 
counts. Journal of Wildlife Management 53(4): 1009-1010.

HIRST, S.M. 1969. Road-strip census techniques for wild ungulates in African woodland. Journal of Wildlife Management 33 (1): 40-48.

JoLLY, G.M. 1969. The treatment of errors in aerial counts of wildlife populations. East African Agricultural \& Forestry Journal, Special Issue, 34: 50-55.

LeResche, R.E. \& R.A. Rausch. 1974. Accuracy and precision of aerial moose censusing. Journal of Wildlife Management 38: 175-182.

McCullough, D.R. 1994. What do herd composition counts tell us? Wildlife Society Bulletin 22(2): 295-300.

Melton, D.A. 1978. Undercounting bias of helicopter census in Umfolozi Game Reserve. Lammergeyer 26: 1-6.

NORTON-GRIFFITHS, M. 1978. Reducing counting bias in aerial census by photography. East African Wildlife Journal 12: 245-248.

Otten, M. R.M.; J. B. Haufler; S. R. Winterstein \& L. C. BENDER. 1993. An aerial censusing procedure for elk in Michigan. Wildlife Society Bulletin 21(1): 73-80.

PAYNE, N. F. 1981. Accuracy of aerial censusing for beaver colonies in Newfoundland. Journal of Wildlife Management 45(4): 1014-1016.
Pennycuick, C.J. \& D. Western. 1972. An investigation of some sources of bias in aerial transect sampling of large mammal populations. East African Wildlife Journal 10: 175-191.

ReILLY, B.K. 2000. The statistics of helicopter total counts of large ungulates in sourish mixed bushveld, northwest arid bushveld and mopane veld, Republic of South Africa. Unpublished $\mathrm{PhD}$ thesis, University of Stellenbosch.

RicE, W.R. \& J.D. HARDER. 1977. Application of multiple aerial sampling to mark-recapture census of white-tailed deer. Journal of Wildlife Management 41: 197-206.

SEBER, G.A.F. 1992. A review of estimating animal abundance II. International Statistical Review 60(2): 129-166.

Van Hensbergen, H.J., M.P.S. Berry \& J. Juritz. 1996. Helicopter based line transect estimates of African herbivore populations. South African Journal of Wildlife Research 26(3): 81-87.

Van LaVieren, L.P. \& Esser. J.D. 1979. Numbers, distribution and habitat preference of large mammals in Bouba Ndjida National Park, Cameroon. African Journal of Ecology 17: 141-153. 